\title{
EKSPANSI "TRUST” DALAM EVALUASI PENDIDIKAN MENITI KREADIBILITAS HASIL BELAJAR
}

\author{
Ali Akbarjono \\ Dosen Fakultas Tadris IAIN Bengkulu \\ Email: aliakbarj250975@gmail.com
}

\begin{abstract}
Evaluation of Education is as a subsystem of implementing management of education that positionedas an educational institution having a centralistic position and becoming a media that accommodates the public assessment of the outcomes (output and outcome) achieved. Through the optimization of education evaluation evaluation has a positive impact on the cultivation of the values of public trust as one of the factors that contribute to the success of management of an educational institution because without buliding and actualizing trust well, the public only as a spectator who has apathy character of the effort of quality development both ranging from input quality, process and output. Ideally the implications of optimizing the implementation of the evaluation mechanism of education can be an instrument of the process of comparing the existing situation with certain criteria to the problems associated with academic in an educational institution because the evaluation of education is actually not only assessing the learning outcomes of students in a certain level of education, regarding the assessment of various aspects affecting the student's learning process, such as evaluation of teachers, curriculum, methods, means of infrastructure, environment and so on. In general the scope of evaluation in the field of education in schools includes three main components namely: Evaluation of teaching programs, Evaluation of teaching implementation process, and Evaluation of learning outcomes.
\end{abstract}

Keyword: Evaluation of Education, and Public Trust.

Abstrak: Evaluasi Pendidikan sebagai subsistem dalam manajemen penyelenggaraan dan pengelolaan suatu lembaga pendidikan berposisi sentralistik dan menjadi media yang mewadahi penilaian publik terhadap hasil (output and outcome)yang telah digapai. Melalui optimalisasi pelakasanaan evaluasi pendidikan memberi dampak positif pada penanaman nilai-nilaikepercayaan publik sebagai salah satu faktor yang turut mendorong kesuksesan pengelolaan suatu lembaga pendidikan karena tanpa adanya kepercayaan yang terbangun dan terbina dengan baik, masyarakat hanya sebagai penonton yang memiliki karakter apatis terhadap upaya pengembangan mutu baik mulai dari mutu input, proses dan output. Idealnya implikasi dari optimalisasi pelaksanaan mekanisme evaluasi pendidikan dapat menjadi instrumen proses membandingkan situasi yang ada dengan kriteria tertentu terhadap masalah-masalah yang berkaitan dengan akademik pada suatu lembaga pendidikan karenaevaluasi pendidikan sebenarnya tidak hanya menilai tentang hasil belajar para siswa dalam jenjang pendidikan tertentu, melainkan juga berkenaan dengan penilaian terhadap berbagai aspek yang mempengaruhi proses belajar siswa tersebut, seperti evaluasi terhadap guru, kurikulum, metode, sarana prasarana, lingkungan dan sebagainya. Secara umum ruang lingkup dari evaluasi dalam bidang pendidikan di sekolah mencakup tiga komponen utama yaitu: Evaluasi program pengajaran, Evaluasi proses pelaksanaan pengajaran, dan Evaluasi hasil belajar.

Kata Kunci: Evaluasi Pendidikan dan Kepercayaan Publik

\section{Pendahuluan}

Pendidikan sebagai bagian terpenting bagi kehidupan manusia yang mampu menghantarkan menjadi pribadi mulia. Artinya pendidikan dapat dijadikan sebagai investasi masa depan yang membuka jalan bagi manusia untuk meningkatkan potensi kualitas hidupyang mampu menyesuaikan diri dengan tuntutan perkembangan zaman dan peradaban, antara lain diindikasikan dengan adanya

\footnotetext{
178 NUANSA Vol. X, No. 2, Desember 2017
}

berkembanganilmu pengetahuan dan teknologi. Pendidikan juga berperan memberi manfaat pribadi dan manfaat sosial, karena dapat menghantar manusia memiliki sikap hidup bermartabat sehingga dapat memposisikan diri secara elegan di masyarakat sebagaimana yang diharapkan dalam regulasi pendidikan bahwa "Pendidikan adalah usaha sadar dan terencana untuk mewujudkan suasana belajar dan proses pembelajaran agar peserta 
didik secara aktif mengembangkan potensi dirinya untuk memiliki kekuatan spiritual keagamaan, pengendalian diri, kepribadian, kecerdasan, akhlak mulia, serta keterampilan yang diperlukan dirinya, masyarakat, bangsa, dan negara".2

Menjembatani implikasi dari pelaksanaan pendidikan itu sendiri tentunya sekolah/madrasahsebagai suatu institusi yang siap mewadahi penyelenggaraan pendidikan sangat berperan dalam mengakomudir pemenuhankebutuhan akan pendidikan. Sekolah juga berperan sebagai tumpuan harapan masyarakat, lembaga pencetak manusiamanusia yang cerdas, terampil, mandiri, berbudaya, dan berkarakter. Harapan dan tumpuan besar ini sesungguhnya akan terealisasi karena adanya sikap mental berupa "kepercayaan/trust" yang tertanam dalam pribadi masyarakat terhadap keberlangsungan institusi pendidikan yang bernama sekolah atau madrasah.

Dengan demikian sungguh besar tanggung jawab sekolah untuk dapat berperan dalam rangka mengemban kepercayaa yang diberikan masyarakat. Publik/ masyarakat dengan menaruh kepercayaan, memiliki harapan besar terhadap pengelola sekolah untuk dapat berbuat optimal dan maksimal dalam menggapai harapan dan tuntutan tersebut sebagaimana pernyataan Menteri Agama RI Lukman Hakim Saifuddin dalam suatu kesempatan, bahwa kepercayaan masyarakat terhadap pendidikan Islam semakin tinggi. Peluang lembaga pendidikan Islam misalnya luar biasa meningkat. Hal ini bisa kita lihat makin tingginya kepercayaan orang tua untuk mencari pendidikan berbasis agama, khususnya Islam dalam menyekolahkan putra-putrinya. Kita bisa melihat, dewasa ini, menjamur pendidikan Islam terpadu, pesantren modern dangan sistem boarding school, meski biaya pendidikannya tinggi. Jangan sampai peluang ini melayang, kita harus menyiapkan diri sebaik mungkin. ${ }^{3}$

Kepercayaan masyarakat terhadap sekolah dapat dibangun dengan berbagai usaha, diantaranya dengan menghadirkan dan mengembangkan program unggulan yang populer, yang dapat memberikan nilai tambah dan langsung berhubungan dengan kebutuhan dasar masyarakat. Terlebih, kulu

${ }^{1}$ Dosen Tetap Fakultas Tarbiyah-Tadris dan Pascasarjana IAIN Beng${ }^{2}$ Undang-Undang Nomor 20 tahun 2003 tentang sistem pendidikan nasional, pasal 1 ayat 1

${ }^{3}$ Lukman Hakim Saifuddin, Menteri Agama RI. sambutan pada Pembukaan Konferensi Penulisan Karya Ilmiah ke-I di Gedung Serbaguna, Madrasah Insan Cendekia Serpong, Banten, Selasa (20/10).https://www2. kemenag.go.id/berita/299185/menag-kepercayaan-masyarakat-terhadappendidikan-islam-semakin-tinggi kebijakan pendidikan dewasa ini memberi keleluasaan dan otonomi pada tiap sekolah, baik sekolah negeri maupun swasta untuk meningkatkan mutu atau kualitasnya dengan cara dan melalui programprogram unggulan yang mampu mereflikasikan peningkatan rasa peduli dan kepercayaan publik masing-masingnnya. Salah satu upaya meningkatkan mutu proses dan kualitas pembelajaran di sekolah antara lain adalah dengan mengembangkan program yang berkaitan dengan kebutuhan penguatan evaluasi pendidikan. Pada satu sisi, pelaksanaan evaluasi pendidikan dengan penilaian hasil belajar yang dilakukan dengan baik dapat diketahui tingkat kemajuan belajar siswa, kekurangan, kelebihan, dan posisi siswa dalam kelompok. Pada sisi yang lain, penilaian hasil belajar yang baik akan merupakan feed back bagi pengelola lembaga pendidikan untuk mengevaluasi tingkat keberhasilan proses belajar mengajar.

Idiealnya, penilaian pada bidang apapun dilakukan dengan menggunakan prosedur dan instrumen yang berstandar dengan mutu yang diinginkan. Artinya prosedur penilaian yang dilakukan dengan menggunakan langkah-langkah tertentu dan perlakuaan yang adil pada siswa dengan mempertimbangankan situasi waktu, tempat, dan berbagai keragaman pada siswa. Sedangkan instrumen yang standar adalah instrumen yang disusun menggunakan prosedur pengembangan instrumen yang baku dan dapat dipertanggungjawabkan tingkat validitas dan reliabilitasnya.

Akan tetapi secara faktual di lapangan menunjukkan potret kontrakdiktif dengan yang semestinya dilaksanakan dan dipenuhi oleh pengelola lembaga pendidikan melalui tenaga pendidik dan kependidikan yang ada. fenomena ini terus saja mengeranyam dalam lingkup evaluasi pendidikan sebagai sarana verifikasi dan pembuktian hasil pembelajaran yang dilaksanakan oleh pengelola suatu lembaga pendidikan. Selanjutnya kondisi ini menjadi viral, topik pembicaraan dan pembahasan yang hangat berkembang di tengah masyarakat, khusunya para politisi, pengamat, dan praktisi pendidikan Indonesia saat ini adalah tentang kegaduhan pelaksanaan UN yang dinilai 'gagal' oleh banyak kalangan.

Akhir-akhir ini memprihatinkan bagi dunia pendidikan di Indonesia karena berbagai program dan kegiatan pendidikan berskala nasional menurut beberapa kalangan dinilai gagal, seperti program Rintisan Sekolah Berstandar Internasional (RSBI), Sekolah Berstandar Internasional (SBI), Uji Kompetensi Guru (UKG), dan terakhir Ujian Nasional (UN). Kegagalan demi kegagalan makin membuat 
dunia pendidikan di Indonesia di era persaingan global semakin tertinggal jauh dengan negara lain, terlebih dengan Malaysia dan Singapura, yang merupakan tetangga terdekat serta tidak jauh berbeda dalam perjalanan sejarah berdirinya negara masing-masing.

Ketertinggalan ini diperparah dengan berbagai kebijakan yang berkaitan dengan pendidikan Indonesia yang membuat dunia pendidikan kita semakin tertinggal seperti program pemetaan hasil evaluasi pendidikan yang dilaksanakan secara serentak sesuai dengan tingkatan satuan pendidikan masingmasingnya di seluruh daerah negeri ini.

Salah satu potret dari kondisi faktula ini menunjukkan fenomena dimana menjelang Ujian $\mathrm{Na}-$ sional (UN) hampir selalu terjadi pergeseran titik tumpu harapan sukses belajar dari jantung sekolah ke punggung lembaga bimbingan belajar (BimBel). Sehingga, ada kecenderungan saat anak memasuki kelas akhir, apalagi pada bulan-bulan menjelang $\mathrm{UN}$, para orang tua beramai-ramai memercayakan pembelajaran anaknya kepada bimbel.

Perilaku pengguna jasa pendidikan seperti itu dapat menjadi indikasi positif jika ukurannya sekadar eksplorasi solusi untuk menghadapi UN dan indeks peningkatan instant semangat belajar. Pada sisi lain animo besar belajar ke BimBel layak menjadi bahan teguran bagi ketuntasan sekolah dalam menyelenggarakan pendidikan. Jangan-jangan perilaku para orang tua seperti itu mengindikasikan penurunan kepercayaan (trust) masyarakat terhadap pembelajaran di sekolah.

Jika penurunan trust itu benar, layak dipertanyakan mengapa terus terjadi setiap tahun, saat makin banyak sekolah yang tegas-tegas mencitrakan diri atau statusnya sebagai sekolah unggul, internasional, saat sebagian besar guru telah bersertifikat profesional, saat durasi waktu belajar di sekolah bertambah panjang, serta alokasi anggaran pendidikan nasional sudah lama mencapai prosentase besar (20\%) dari APBN.

Berangkat dari fenomena tentang memudarnya nilai kepercayaan publik terhadap kebijakan publik dalam sistem pengelolaan lembaga pendidikan yang ada pada setiap satuan pendidikan dimana menunjukkan implikasi dari kejanggalan dalam menerapkan sistem dan mekanisme evaluasi pendidikan yang dilalukan oleh pengelola lembaga pendidikan itu sendiri. Dari fenomena faktual yang kerap terjadi di dunia pendidikan kita menggerak hati penulis sebagai praktisi pendidikan untuk menggali secara teoritis dan akademis melalui literatur yang ada kiranya dapat menjadi salah satu alternatif solusi menyikapi dan mereduksi ketidak-percayaan publik terhadap hasil pendidikan yang dihasilkan oleh suatu lembaga pendidikan.

\section{Rumusan Masalah}

Dari uraian latar belakang di atas dapat di rumuskan masalah dalam artikel ini adalah sejauhmana keterlibatan sikap mental kepercayaan terhadap lembaga pendidikan dalam kaitannya dengan prosesi pelaksanaan evaluasi pendidikan; dan bagaimana semestinya penerapan evaluasi pembelajarn di sekolah benar-benar dapat menumbuhkembangkan kepercayaan publik terhadap mutu penyelenggaraan pendidikan?

\section{Tujuan}

Berdasarkan uraian latar belakang dan rumusan masalah di atas dapat di tuliskan tujuan penulisan artikel ini adalah; (a) memberi sebuah pemahaman yang konkrit tentangsejauhmana keterlibatan sikap mental kepercayaan terhadap sistem pengelolaan lembaga pendidikan dalam kaitannya dengan prosesi pelaksanaan evaluasi pendidikan; (b) dan dapat menerapkan sistem dan mekanisme evaluasi pembelajarn di sekolah benar-benar dapat memberikan kepercayaan publik terhadap mutu penyelenggaraan pendidikan.

\section{Pembahasan}

\section{A. Konsep Dimensi Kepercayaan (trust) dalam dunia pendidikan}

Kepercayaan berasal dari kata percaya atau dalam bahasa Inggris diistilahkan dengan trust, artinya mengakui atau meyakini akan kebenaran. Jadi kepercayaan adalah kemauan seseorang untuk bertumpu pada orang lain dimana kita memiliki keyakinan padanya. Kepercayaan merupakan kondisi mental yang didasarkan oleh situasi seseorang dan konteks sosialnya.

Dengan kata lain kepercayaan, adalah isu sentral dalam peradaban kehidupan manusia. Begitu sentralnya pengaruh kepercayaan karena karakter ini juga menempati posisi penting dalam sebuah organisasi. Bagaimana tidak, begitu banyak organisasi yang jatuh dan bangun dikarenakan isu ketidakpercayaan. Isu pentingnya penanaman nilai-nilai kepercayaan dalam dinamika prosesi pengelolaan suatu organisasi dalam hal ini institusi pendidikan sebagaimana yang tergambar dalam bagan berikut; ${ }^{4}$

${ }^{4}$ Starnes, Becky J. et.al. A Primer on Organizational Trust. Downloaded
http://rube.asq.org/hdl/2010/06/a-primer-on-organizational-trust. 
Ali Akbarjonol Ekspansi “TRUST" Dalam Evaluasi Pendidikan 181

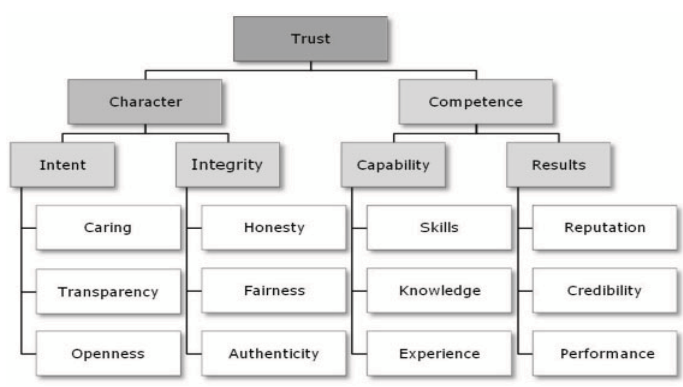

Gambar.2.1

Konsep tentang kepercayaan

Para ahli di bidangnya memaknai kepercayaan berdasarkan kontekstual, antara lain; Becky J. Starnes memaparkan tiga konsep tentang kepercayaan, yaitu; "The belief in the integrity, character, and ability of a leader; "Reciprocal faith in one's intentions and behaviors; "A confidant reliance on the integrity, honesty, or justice of another ${ }^{4}$ Artinya Stanes memaknai kepercayaan pada tiga tataran, yaitu: (a) "Kepercayaan pada integritas, karakter, dan kemampuan seorang pemimpin, (b) "percaya yang bersifat timbal balik dalam niat dan perilaku seseorang, dan (c) "Sebuah ketergantungan kepercayaan pada integritas, kejujuran, keadilan pada orang lain.

Stephen P. Robbins memaknai kepercayaan "(trust)is psychological state that exists when you agree to make yourself vulnerable to another because you have positive expectations about how things are going to turn out". 5

Artinya bahwa kepercayaan itu dianggap sebagai pernyataan psikologis yang muncul pada saat pimpinan setuju untuk membuat yakin kepada orang lain karena memiliki harapan positif tentang bagaimana sesuatu akan berjalan.

Lebih lanjut Robbins menganggap kepercayaan (trust) sebagai atribut utama dalam kepemimpinan, yaitu melalui pernyataan:"trust is a primary attribute associated with leadership; breaking it can have serious adverse effects on a group's performance".

Mayer memberikan definisi kepercayaan "(trust) is the willingness of a party to be vulnerable to the actions of another party based on the expectation that the other will perform a particular action important to the trustor, irrespective of the ability to monitor or control that other party".7 Konsep keper-

${ }^{5}$ Robbins, Stephen P. And Timothy A.Judge. 2011. Organizational Behavior. (New York: Prentice Hall.2011).h.395.

${ }^{\circ}$ Robbins, Stephen P. Ibid. h.95.

${ }^{7}$ Mayer et al. 1995. Academy of Management Review. downloaded from http://www.ooa.nl/download/?id=16112122. cayaan menurut Mayer ini dapat dimaknai berupa keinginan suatu pihak untuk menjadi pasrah/menerima tindakan dari pihak lain berdasarkan pengharapan bahwa pihak lain tersebut akan melakukan sesuatu tindakan tertentu yang penting bagi pihak yang memberikan kepercayaan, terhadap kemampuan memonitor atau mengendalikan pihak lain.

Doney and Cannonmendefinisikan kepercayaan:

trust as "the perceived credibility and benevolence of a seller or his sales person"; (a) The dimension of credibility refers to the expectation that a client can rely on seller's statements; (b) The dimension of benevolence refers to the consideration that a seller is interested on his client's benefits and welfare. ${ }^{8}$

Dalam konteks ini Doney dan Cannon memberikan definisi kepercayan sebagai sesuatu yang diharapkan dari kejujuran dan perilaku kooperatif yang berdasarkan saling berbagi norma-norma dan nilai yang sama terutama terhadap diri klien.percaya sebagai "kredibilitas dirasakan dan kebajikan dalam hal pemasaran, yaitu adanya dimensi kredibilitas mengacu pada harapan bahwa klien dapat mengandalkan pernyataan penjual menjadi dimensi kebajikan mengacu pada pertimbangan bahwa penjual tertarik pada manfaat dan kesejahteraan kliennya.

Morgan dan Hunt, "trust as existing who one party has 's confidence in an exchange partner's realibility and integrity". Artinya bahwa kepercayaan sebagai salah satu keyakinan yang dimiliki oleh pihak kepada orang lain karena keandalan dan integritas. Dengan kata lain bahwa kepercayaan timbul karena adanya suatu rasa percaya kepada organisasi yang memang mempunyai kualitas yang dapat mengikat dirinya, seperti tindakannya yang konsisten, kompeten, jujur, adil, bertanggung jawab, suka membantu dan rendah hati (benevolent).

David L.Goetsch dan Stanley B.Davis, "trust is a necessary ingredient for success in the intensely competitive modern workplace."10 Artinya bahwa kepercayaan (trust) sebagai materi penting yang diperlukan untuk bisa sukses di tempat kerja modern yang sangat kompetitif.

${ }^{8}$ Doney. Toward A Trustful B To B Relationship.published in International Journal of Business and Management. October, 2009.

${ }^{9}$ Morgan, Robert M dan Shalby D. Hunt. 1994. The commitment- trust theory. Published in Journal of marketing, July 1994. h. 23.

${ }^{10}$ Goetsch, David L dan Stanley B.Davis.Quality management: introduction to total quality management for production, procesing, and services. (USA Prentice Hall. 2000).h.258. 
Dengan kata lain D.Zielinski dan C.Busse dalam David L. Goetsch memposisikan kepercayaan dalam dunia kerja begitu urgen untuk dipahami oleh pemimpin dalam menjalani dinamika kerja sehingga karyawan sebagai bawahan dapat bekerja dengan kreatif, inovatif, serta mampu mengambil sikap inisiatif tanpa takut rekriminasi dari manajemen:"(employees who can make hard decisions, access key information, and take inniative without fear of recrimination from mangement, and managers who believe their people can make the right decisions) "."1

Wibowo mengargumentasikan kepercayaan (trust) sebagai bentuk nilai yang paling dihargai dalam hubungan antar manusia dan mungkin merupakan konsep yang kurang dimengerti ditempat kerja atau rasa percaya yang dimiliki orang terhadap orang lain. ${ }^{12}$

Kepercayaan akan datang dengan sendirinya, sesuai dengan sikap yang seseorang. Kepercayaan mudah sekali luntur. Sekali saja berbohong maka akan sulit untuk dipercaya lagi, bahkan sampai diberi label pembohong. Maka untuk mendapatkan kepercayaan bukan hal yang mudah dan membutuhkan waktu yang lama.

Menurut Von Krogh (dalam Kim \& Lee) kepercayaan dan keterbukaan dalam budaya organisasi mendorong berbagi pengetahuan di antara karyawan dan perilaku yang layak dipercaya meningkatkan kecepatan komunikasi dengan memberikan wewenang pada rekan kerja dalam berbagi masalah dan pengetahuan pribadi dengan lebih leluasa. ${ }^{13}$

Nonaka \& Takeuchi mengamati bahwa hubungan yang loyal dan saling mempercayai, dapat mengurangi kecurangan, dan penipuan di antara karyawan dengan cara menyalahkan orang lain atas kegagalan organisasi. ${ }^{14}$

Kepercayaan juga merupakan salah satu faktor yang turut mendorong kesuksesan suatu lembaga. Kepercayaan merupakan motivasi yang mendorong bawahan atau karyawan untuk terlibat aktif dalam membangun dan memajukan lembaga itu sendiri. Tanpa adanya kepercayaan yang terbangun dan terbina dengan baik, siapapun sebagai bawahan akan kehilangan minat, inisiatif dan motivasi dalam bekerja. Artinya manakala seorang bawahan kehilangan kepercayaan terhadap manajemen lembaga, maka hal itu menjadi pertanda buruk bagi lembaga itu sendiri. ${ }^{15}$

\footnotetext{
${ }^{11}$ Goetsch, David L. Ibid. h.85.

${ }^{12}$ Wibowo. Manajemen Perubahan, (Jakarta: PT Raja Grafindo Persada,

${ }^{13} \mathrm{Kim}, \mathrm{S} . \&$ Lee, H. (2006). The impact oforganizational context and informationtechnology on employee knowledgesharing capability. Public AdministrationReview. 66,3. Diakses dari www.blackwellsynergy.com pada tanggal 3 Mei 2015.

${ }^{14}$ Nonaka, I. \& Takeuchi, H. The knowledge creating company. HowJapanese companies create the dynamics of innovation. (New York: oxford universitypress. 1995)
} 2006). h. 376 organisasi/
Kepercayaan memerlukan waktu untuk berkembang; kepercayaan mudah hilang dan sulit untuk didapatkan kembali. Kepercayaan adalah elemen yang rentan, namun pasti diperlukan dalam hubungan-hubungan apa pun. Dengan pertama-tama mempercayai diri sendiri, dimungkinkan bagi para pemimpin untuk mengembangkan rasa peduli (caring), hubungan yang tulus (genuine), serta membangun kepercayaan dengan orang-orang yang dipimpinnya dan memungkinkan mereka untuk mengembangan hubungan yang efektif satu sama lain.

Dari uraian di atas mengenai kajian tentang kepercayaan yang diungkapkan oleh beberapa ahli di bidangnya, maka kepercayaan dalam konteks respon publik terhadap kinerja lembaga pendidikan melalui kinerja tugas guru dalam melakukan proses kegiatan belajar mengajar terutama dalam pelaksanaan evaluasi pembelajaran. Secara praktis memang nilai ini merupakan faktor paling krusial dalam setiap relasi, sekaligus berpengaruh pada komitmen. Prilaku ini bisa juga diartikan sebagai kesediaan untuk mengandalkan kemampuan, integritas dan motivasi pihak lain untuk bertindak dalam rangka memuaskan kebutuhan dan kepentingan seseorang sebagaimana disepakati bersama secara implisit maupun eksplisit.

Konsekuensi secara psikologis yang dipengerahui oleh nilai adanya kepercayaan yang terbina dengan baik dalam suatu komunitas kerja, maka orang-orang bersemangat tentang apa yang mereka lakukan. Mereka berkolaborasi dengan bebas, saluran-saluran komunikasi terbuka, berbagi ide menjadi norma, dan orang-orang tidak takut untuk membuat kesalahan-kesalahan. Mereka bangga dengan organisasi tempat mereka bekerja, berkomitmen kepada orang-orang yang bekerja bersama dengan mereka, dan membawa diri mereka lebih sepenuhnya (fully) dalam melakukan pekerjaan-pekerjaan mereka. Dalam mempercayai lingkungan, orangorang dapat memfokuskan diri pada pekerjaan mereka; mereka lebih produktif dan ingin datang ke tempat kerja.

Dalam operasionalnya Kepercayaan dan manajemen pengelolaan lembaga pendidikan memiliki hubungan yang signifikan satu sama lain. Kepercayaan sangat menentukan keberhasilan penyelenggaraan suatu pendidikan yang diharapkan memberi dampak positif bagi publik berupa hasil pembelajaran yang bermutu dan terpakai di masyarakat.

Sekolah atau madrasah adalah institusi penting sebagai bagian dari upaya masyarakat melakukan 
perbaikan terhadap kehidupannya hari ini dan esok. melalui sekolah, individu diajarkan cara berfikir, bertindak, dan bentuk-bentuk keterampilan yang penting bagi kehidupannya. peran penting sekolah tersebut juga merambah kepada aspek-aspek sosial seperti kemampuan berkomunikasi, membangun hubungan sosial, sampai kemampuan berempati.

Dalam kaitannya dengan upaya membangun kepercayaan, beberapa hal yang bisa dilakukan sekolah antara lain melakukan transparansi penyelenggaraan pendidikan, menjalin komunikasi yang terbuka dengan masyarakat,danmeningkatkan kemampuan guru dalam menyelenggarakan pembelajaran.Transparansi penyelenggaraan pendidikan merupakan upaya yang dilakukan sekolah dalam memberi ruang bagi masyarakat untuk mengakses informasi tentang penyelenggaraan pendidikan di sebuah sekolah.

Transparansi menjadi penting dalam dua aspek, membangun kepercayaan masyarakat kepada sekolah dan mencontohkan keterbukaan kepada peserta didik dan masyarakat. dalam upaya membangun kepercayaan, sekolah perlu memberikan informasi kepada masyarakat tentang "apa dan bagaimana" proses pendidikan yang telah, sedang, dan akan dilaksanakannya. dengan cara ini masyarakat bisa memberikan penilaian terhadap kredibilitas sekolah dan pada saat yang sama memiliki kemampuan untuk memprediksi apa yang akan dilakukan oleh sekolah kepada peserta didik yang dipercayakan kepadanya. banyak fakta membuktikan bahwa sekolah yang mengalami kemunduran adalah sekolah yang terlalu tertutup dan tidak memberikan kesempatan kepada masyarakat untuk mengetahui apa yang dilakukan oleh sekolah.

\section{B. Ruang Lingkup Penilaian Hasil Belajar}

Secara umum Evaluasi pendidikan pada prinsipnya dapat dikelompokkan menjadi tiga cakupan penting, yaitu; (a) Evaluasi Pembelajaran: inti bahasan evaluasi yang kegiatannya dalam lingkup kelas atau dalam lingkup proses belajar mengajar. Evaluasi ini merupakan evaluasi yang dilakukan oleh pendidik yang berkaitan dengan materi pembelajaran; (b) - Evaluasi Program: bahasan yang lebih luas yaitu mulai dari evaluasi kurikulum sampai pada evaluasi program dalam suatu bidang studi. Sesuai dengan cakupan yang lebih luas maka yang menjadi objek evaluasi program juga dapat bervariasi, termasuk diantaranya kebijakan program, implementasi program dan efektifitas program; (c) Evaluasi Kelembagaan: evaluasi dibidang yang terkait dengan kinerja kelembagaan didalam mengemban tugas-tugas kelembagaan sesuai dengan visi dan misinya. ${ }^{16}$

Kemajuan dunia pendidikan Indonesia tidak hanya diukur dengan tingkat kesuksesan pelaksanaan dan keberhasilan Ujian Nasional (UN) saja tetapi banyak faktor dan indikator yang diperhitungkan dalam menilai tingkat kemajuan dan proses keberlangsungan pelaksanaan kegiatan belajar-mengajar yang diimplementasikan pada setiap satuan pendidikan. Selama ini kita terpesona dengan keberhasilan pelaksanaan dan hasil atau nilai Ujian $\mathrm{Na}-$ sional (UN) yang diperoleh para siswa, pada hal kita lupa bahwa hasil UN merupakan angka kualitatif yang semu dan tidak menggambarkan keberhasilan dunia pendidikan yang sesungguhnya.

Ada anggapan dan kemudian menjadi pembenaran bahwa siswa yang memperoleh nilai UN adalah anak yang pinter dan cerdas serta menjadi figur yang patut untuk dicontoh oleh siswa yang lain. Demikian pula dengan sekolah yang berhasil meluluskan siswanya dengan perolehan nilai UN yang tinggi dianggap sekolah yang berhasil dan menjadi incaran siswa untuk masuk dan bersekolah di sekolah tersebut. Hal inilah yang kemudian menjadi bernilai dan berharganya UN dimata siswa dan masyarakat yang membangga-banggakan prestasi akademik. Seseorang dapat dikatakan telah berhasil dalam belajar jika ia mampu menunjukkan adanya perubahan dalam dirinya. Perubahan-perubahan tersebut dapat ditunjukkan diantaranya dari kemampuan berpikirnya, keterampilannya, atau sikapnya terhadap suatu obyek. Perubahan dari hasil belajar ini dalam TaxononiyBloomdikelompokkan dalam tiga ranah (domain), yakni: (1) domain kognitif atau kemampuan berpikir, (2) domain afektif atau sikap, dan (3) domain psikomotor atau keterampilan.

Peserta didik dapat dikatakan berhasil dalam belajar jika pada diri mereka telah terjadi perubahan dari minimal salah satu aspek di atas. Contoh perubahan dalam aspek kemampuan berpikir misalnya dapat terjadi jika terjadi perubahan dari tidak tahu menjadi tahu, atau perubahan dari tidak paham menjadi paham dan seterusnya. Contoh perubahan aspek sikap misalnya dari sikap yang buruk menjadi sikap yang baik, atau dari semula bersikap tidak sopan menjadi sikap yang sopan dan seterusnya. Contoh perubahan dalam aspek keterampilan misalnya, dari tidak dapat melakukan wudlu menjadi terampil berwudlu, dari tidak terampil melukis menjadi terampil melukis dan seterusnya. ${ }^{17}$

\footnotetext{
${ }^{16}$ Winarno, Agung. 2014. Pengantar Pendidikan. Malang: Universitas Negeri Malang

${ }^{17}$ Rasyid, dkk. 2007. Penilaian Hasil Belajar.Bandung: CV. Wacana Prima. hal 78
} 
Dalam pelaksanaan penilaian dalam konteks evaluasi pembelajaran sepatutnya mendominasi ketiga ranah atau domain penilaian hasil belajar sebagaimana tersebut di atas, harus dinilai secara menyeluruh, sebab prestasi belajar siswa seharusnya menggambarkan perubahan menyeluruh sebagai hasil belajar siswa. Untuk itulah guru atau pendidik dituntut untuk memahami dan menguasai beberapa aspek perubahan teknik untuk menilai beberapa aspek perubahan belajar peserta didik.

Masing-masing tingkatan dalam setiap ranah atau domain menuntut kemampuan atau kecakapan yang berbeda-beda dari setiap peserta didik untuk memberikan respon terhadapnya. Semakin tinggi tingkatan yang dituntut semakin tinggi pula tingkat kompleksitas jawaban atau respon yang dikehendaki. Untuk kepentingan ini, maka seorang guru harus memahami bahwa semakin rendah tingkatan yang diujikan, maka seharusnya semakin rendah pula bobot skor yang diberikan; demikian sebaliknya bahwa semakin tinggi tingkatan yangdiujikan,maka seharusnya semakin tinggi pula bobot skor yang diberikan.

Hal di atas dapat dimaklumi, sebab untuk dapat mencapai kemampuan pada tingkat tertinggi, maka seorang siswa harus menguasai tingkatan di bawahnya sebelumnya; demikian seterusnya. Sebagai contoh, seorang siswa dapat melakukan penerapan (application) suatu rumus misalnya jika sebelumnya ia mampu memahami (comprehension) rumus yang ia terapkan demikian sebaliknya ia akan mampu memahami (comprehension) sesuatu, jika sebelumnya ia mampu atau memiliki pengetahuan (knowledge) tentang sesuatu yang harus ia pahami.

Penilaian hasil belajar peserta didik mencakup kompetensi sikap, pengetahuan, danketerampilan yang dilakukan secara berimbang sehingga dapat digunakan untuk menentukan posisi relative setiap peserta didik terhadap standar yang telah ditetapkan. Cakupan penilaian merujuk pada ruang lingkup materi, kompetensi mata pelajaran atau kompetensi muatan atau kompetensi program dan proses. ${ }^{18}$

Ada dua pendekatan penilaian dalam seni yang sering dipergunakan dalam dunia pendidikan, yaitupendekatan objektif dan pendekatan subjektif (intuitif ). Penerapan penilaian dengan pendekatan objektif maupun intuitif secara ekstem masing-masing mempunyai kelemahan. Pendekatan objektif mempersyaratkan sifat satu dimensi dari objek pen-

${ }^{18}$ Kurniasih, Imas \& Sani, Berlin. (2014). Implementasi Kurikulum 2013 Konsep \& Penerapan. Surabaya: Kata Pena. hal 86-87 gukuran, padahal penilaian dalam seni khususnya pada bidang seni tari pada umumnya objeknya adalah perilaku yang sangat kompleks (multidimensi), dan penampilan yang diamati relatif panjang durasi waktunya, sehingga apabila dilakukan penilaian terhadapnya akan membutuhkan instrumen yang sangat panjang.

Seseorang dapat dikatakan telah berhasil dalam belajar jika ia mampu menunjukkan adanya perubahan dalam dirinya. Perubahan-perubahan tersebut dapat ditunjukkan diantaranya dari kemampuan berpikirnya, keterampilannya, atau sikapnya terhadap suatu obyek. Perubahan dari hasil belajar ini dikelompokkan dalam tiga ranah (domain), yakni: (1) domain kognitif atau kemampuan berpikir, (2) domain afektif atau sikap, dan (3) domain psikomotor atau keterampilan.

Sosok guru merupakan hal yang sangat asasi dalam sebuah pembelajaran, baik pembelajaran yang sifatnya formal atau yang tidak formal, dan supaya peran guru tidak lari dari rel yang ditentukan, maka tentu guru harus tahu dan menjalankan fungsi-fungsinya, baik tugas pokok atau tugas tambahan, pembelajaran yang tidak sukses itu boleh jadi disebabkan oleh tugas sebagai guru tidak berjalan. Dalam perkembangan ilmu keguruan, untuk mencapai keberhasilan dalam pendidikan diperlukan tenaga keguruan yang handal atau lebih dikenal sebagai profesinalisme guru. Ketika profesi keguruan diminati banyak kalangan akademika saat ini maka telah banyak sinergi keguruan yang telah dirintis oleh par ilmuan. Hal ini dikarenakan guru merupakan pondasi dasar bagi kestabilan ekonomi suatu bangsa yang ingin bergerak maju dengan memperliatkan output dari proses sebuah lembaga. Biasanya cerminan hasil atau output dari suatu lembaga pendidikan akan berpijak pula pada kepiawaian, keseriusan, serta tanggung jawab seorang guru dalam mengemban tugas keprofesiannya.

Status guru mempunyai implikasi terhadap peran dan fungsi yang menjadi tanggung jawabnya. Guru memiliki satu kesatuan peran dan fungsi yang tidak terpisahkan, yakni antara kemampuan mendidik, membimbing, mengajar, dan melatih. Keempat kemampuan tersebut merupakan kemampuan terintegrasi yang tidak dapat dipisahkan satu dengan lainnya. Seorang guru yang dapat mendidik, tetapi tidak memiliki kemampuan membimbing, mengajar, dan melatih, tidak dapat dikatakan guru yang paripurna.

Guru sebagai sosok teladan, sosok yang di ditiru sudah sewajarnya jika selalu ingat akan tupoksi atau tugas pokok dan fungsi sebagai seorang guru, 
dengan demikian ketika seorang guru senantiasa memperhatikan, mengingat dan menjalankan apa yang menjadi tupoksinya maka ia berhak menyandang gelar guru profesional. Tupoksi merupakan satu kesatuan yang saling terkait antara tugas pokok dan fungsi. Dalam peraturan perundang-undangan tentang organisasi dan tata kerja suatu kementerian negara/lembaga sering disebutkan bahwa suatu organisasi menyelenggarakan fungsi-fungsi dalam rangka melaksanakan sebuah tugas pokok.

\section{A. Penilaian Kompetensi Sikap}

\section{a. Pengertian Penilaian Kompetensi Sikap}

Sikap bermula dari perasaan yang terkait dengan kecenderungan seseorang dalam merespons sesuatu atau objek.sikap terdiri dari tiga komponen, yakni: afektif, kognitif, dan konatif. ${ }^{19}$

Afektif adalah perasaan yang dimiliki seseorang atau penilaianya terhadap sesuatu objek. Kognitif adalah kepercayaan atau keyakinan seseorang mengenai objek. Konatif adalah Kecenderungan untuk berprilaku dengan cara-cara tertentu berkenaan dengan kehadiran objek sikap.

Dari penjelasan diatas dapat dikemukakan bahwa penilaian kompetensi sikap adalah penilaian yang dilakukan guru untuk mengukur tingkat pencapaian kompetensi sikap dari peseta didik yang meliputi aspek menerima atau memerhatikan, merespons atau menanggapi, menilai atau menghargai, mengorganisasiatau mengelola,dan berkarakter.

\section{b. Ruang Lingkup Penilaian Kompetensi Sikap}

Dalam ranah sikap itu terdapat lima jenjang proses berpikir, yakni : ${ }^{20}$

(1) menerima atau memerhatikan (receiving atau attending; (2) merespons atau menanggapi (responding; (3) menilai atau menghargai (valuing); (4) mengorganisasi atau mengelola (organization); (5) berkarakter (charakterization).

Berikut ini penjelasan masing-masiing proses berfikir afektif (sikap):

1) Kemampuan Menerima

Kemampuan Menerima adalah kepekaan seseorang dalam menerima stimulus dari luar yang datang kepada dirinya dalam bentuk masalah, situasi, gejala dan lain-lain. Kemampuan menerima juga diartikan kemempuan menunjukkan perhatian menerima fenomena dan stimu-

${ }^{19}$ Kunandar, 2013. Penilaian Autentik (Penilaian Hasil Belajar Peserta Didik Berdasarkan Kurikulum 2013) Suatu Pendekatan Praktik Disertai dengan Contoh Jakarta: Rajawali Press. hal 103-104

${ }^{20}$ Kunandar, 2013. Ibid. hal 109-114 lus atau kemempuan menunjukkan perhatian yang terkontrol dan terseleksi. Contoh hesil belajar afektif jenjang menerima adalah peserta didik menyadari bahwa disiplin wajib ditegakkan dan tidak disiplin harus ditinggalkan.

2) Kemampuan Merespon atau Menanggapi Kemampuan merespons adalah kemampuanyang dimiliki oleh seseorang untuk mengikutsertakan dirinya secara aktif dalam fenomena tertentu dan membuat reaksi terhadapnya dengan salah satu cara. Contoh hasil belajar ranah afektif jenjang menanggapi adalah peserta didik tumbuh hasratnya untuk mempelajari lebih jauh lagi tentang disiplin.

3) Kemampuan Menilai atau Menghargai Kemampuan menilai adalah kemampuan memberikan nilai atau penghargaan terhadap suatu kegiatan, sehingga apabila kegiatan itu tidak dikerjakan akan membawa kerugian. Contoh hasil belajar afektif jenjang valuing misalnya, tumbuhnya kemauan yang kuat pada diri peserta didik untuk berlaku disiplin, baik di sekolah, di rumah maupun di tengah-tengah kehidupan masyarakat.

4) Kemampuan Mengatur atau Mengorganisasi Kemampuan Mengatur atau Mengorganisasi artinya kemampuan mempertemukan perbedaan nilai sehingga terbentuk nilai baru yang lebih universal, yang membawa kepada pembaikan umum. Contoh hasil belajar afektif jenjang kemampuan mengorganisasimisalnya, peserta didik mendukung penegakan disiplin nasional.

5) Kemampuan Berkarakter

Kemampuan berkarakter adalah kemampuan memadukan semua sistem nilai yang telah dimiliki seseorang yang memengaruhi pola kepribadian dan tingkah lakunya. Contoh hasil belajar afektif pada jenjang ini adalah siswa telah memiliki kebulatan sikap wujudnya peserta didik menjadikan perintah Tuhan sebagai pegangan hidupnya dalam hal yang menyangkut kedisiplinan, baik kedisiplinan di sekolah, di rumah maupun di tengah-tengah kehidupan masyarakat.

c. Kelebihan dan Kelemahan Penilaian Kompetensi Sikap

Kelebihan dari penilaian kompetensi sikap adalah: Dapat dilakukan bersamaan dengan proses belajar mengajar; Dapat dilakukan secara langsung atau tidak langsung; Dapat mengetahui faktor penyebab keberhasilan atau kegagalan; Mengajak peserta didik untuk bersikap jujur; Mengajak peserta 
didik menjalankan tugasnya tepat waktu; Sikap peserta didik terhadap pelajaran dapat diketahui; Dapat mengetahui faktor-faktor keterbatasan peserta didik.

Kelemahan dari penilaian kompetensi sikap adalah: Sulit dilakukan pada peserta didik yang terlalu banyak; Membutuhkan alat penilaian yang tepat; Memerlukan waktu pengamatan yang cukup lama; Jawaban peserta didik sulit diuji kejujurannya; Guru lebih menanggapi peserta didik yang yang aktif saja.

B. Penilaian Kompetensi Pengetahuan

a. Pengertian Penilaian Kompetensi Pengetahuan

Penilaian kompetensi pengetahuan atau kognitif adalah penilaian yanga dilakukan guru untuk mengukur tingkat pencapaian atau penguasaan peserta didik dalam aspek pengetahuan yang meliputi ingatan, pemahaman, penerapan sintesis dan evaluasi. Dalam kurikulum 2013 kompetensi pengetahuan menjadi kompetensi inti dengan kode kompetensi inti 3 (KI 3$).^{21}$

\section{b. Ruang Lingkup Penilaian Kompetensi Penge-} tahuan

Dalam ranah kompetensi pengetahuan atau kognitif itu terdapat enam jenjang proses berfikir, yakni :22

\section{1) Pengetahuan/hafalan/ingatan (knowledge)}

Pengetahuan adalah kemampuan seseorang untuk mengingat kembali tentang nama, istilah, ide, gejala, rumus-rumus, dan sebagainya tanpa mengharapkan kemampuan untuk menggunakannya. Dalam kegiatan ini belajar dapat ditunjukkan melalui: a) mengemukakan arti, b) memberi nama, c) membuat daftar, d) menentukan lokasi, e) mendeskripsikan sesuatu cerita yang terjadi dan menguraikannya. Contoh hasil belajar yang berkaitan dengan pengetahuan adalah peserta didik dapat menyebutkan berdirinya organisasi ASEAN.

\section{2) Pemahaman}

Pemahaman adalah kemampuan seseorang untuk mengerti atau memahami sesuatu setelah sesuatu itu diketahui atau diingat. Dalam kegiatan belajar ditunjukkan melalui: a) mengungkapkan gagasan, b) mendeskripsikan dengan kata-kata sendiri, c) menjelaskan gagasan pokok, d) menceritakan kembali dengan kata-kata sendiri. Contoh hasil belajar yang berkaitan dengan pemahaman adalah

${ }^{21}$ Sunarti dan Selly Rahmawati. 2014. Penilaian Dalam Kurikulum 2013. Yogyakarta: Penerbit Andi. hal 98

${ }^{22}$ Kunandar, 2013. Op.cit . . hal 165-170 peserta didik dapat menjelaskan makna organisasi ASEAN bagi bangsa Indonesia dalam aspek ekonomi.

\section{3) Penerapan}

Penerapan adalah kesanggupan seseorang untuk menerapkan ide-ide umum, tata cara ataupun metode-metoode, prinsip-prinsip, rumus-rumus, teori-teori, dalam situasi yang baru dan konkret. Penerapan ini adalah proses berfikir setingkat lebih tinggi dari pemahaman. Contoh hasil belajar yang berkaitan dengan penerapan adalah peserta didik dapat memberikan penjelasan upaya yang harus dilakukan organisasi ASEAN dalam menghadapi era globalisasi dan tata ekonomi dunia baru yang penuh dengan tantangan.

\section{4) Analisis}

Analisis adalah kemampuan seseorang untuk merinci atau menguraikan suatu bahan atau keadaan menurut bagian-bagian yang lebih kecil dan mampu memahami hubungan antara bagianbagian atau faktor-faktor yang satu dengan faktor yan lainnya. Dalam pembelajaran ini ditunjukkan melalui: mengidentifikasi faktor penyebab, merumuskan masalah, mengajukan pertanyaan untuk memproleh informasi, membuat grafik dan mengkaji ulang. Contoh hasil belajar yang berkaitan dengan analisis adalah peserta didik dapat mengidentifikasi penyebab pasang surutnya kiprah organiasi ASEAN dalam kancah ragional dan Internasional.

\section{5) Sintesis}

Sintesis adalah kemmapuan berfikir yang merupakan kebalikan dari proses berfikir analisis. Sintesis merupakan suatu proses yang memadukan bagianbagian secara logis sehingga menjelama menjadi suatu pola yang berstrukturatau berbentuk pola baru. Contoh hasil belajar yang berkaitan dengan sintesis adalah peserta didik dapat memprediksi bagaimana kalau organisasi ASEAN itu bubar.

\section{6) Evaluasi}

Evaluasi adalah kemampuan seseorang untuk membuat pertimbangan terhadap suatu situasi, nilai, atau ide. Misalnya jika seseorang dihadapkan pada beberapa pilihan maka ia akan mampu memilih satu pilihan yang terbaik. Contoh hasil belajar yang berkaitan dengan evaluasi adalah peserta didik dapat memberikan evalusai terhadap organisasi ASEAN dalam mewujudkan kawasan Asia Tenggara yang damai dan sejahtera.

\section{Penilaian Kompetensi Keterampilan \\ a. Pengertian Penilaian Kompetensi Kete- rampilan \\ Ranah psikomotorik adalah ranah yang}


berkaitan dengan keterampilan (skill) atau kemampuan bertindak setelah seseorang menerima pengalaman belajar tertentu. Psikomotorik berhubungan dengan hasil belajar yang pencapaiannya melalui keterampilan (skill) sebagai hasil dari tercapainya kompetensi pengetahuan. Hasil belajar psikomotorik sebenarnya merupakan kelanjutan dari hasil belajar kognitif dan hasil belajar afektif (yang baru tampak dalam kecenderungan-kecenderungan untuk berperilaku atau berbuat).

Kompetensi peserta didik dalam ranah psikomotorik menyangkut kemampuan melakukan gerakan refleks, gerakan dasar, gerakan persepsi, gerakan berkemampuan fisik, gerakan terampil, gerakan indah dan kreatif. Jadi, penilaian kompetensi keterampilan adalah penilaian yang dilakukan guru untuk mengukur tingkat pencapaian kompetensi keterampilan dari peserta didik yang meliputi aspek imitasi, manipulasi, presisi, artikulasi, dan naturalisasi. $^{23}$

\section{A. Ruang Lingkup Penilaian Kompetensi Keter- ampilan}

Dalam ranah keterampilan itu terdapat lima jenjang proses berpikir, yakni:

\section{1) Imitasi}

Imitasi adalah kemampuan melakukan kegiatan-kegiatan sederhana dan sama persis dengan yang dilihar atau diperhatikan sebelumnya. Contohnya, seorang peserta didik dapat memukul bola dengan tepat karena pernah melihat atau memperhatikan hal yang sama sebelumnya.

\section{2) Manipulasi}

Manipulasi adalah kemampuan melakukan kegiatan sederhana yang belum pernah dilihat, tetapi berdasarkan pada pedoman atau petunjuk saja. Sebagai contoh, seorang peserta didik dapat memukul bola dengan tepat hanya berdasarkan pada petunjuk guru atau teori yang dibacanya.

\section{3) Presisi}

Kemampuan tingkat presisi adalah kemampuan melakukan kegiatan-kegiatan yang akurat sehingga mampu menghasilkan produk kerja yang tepat. Contoh, peserta didik dapat mengarahkan bola yang dipukulnya sesuai dengan target yang diinginkan.

\section{4) Artikulasi}

Kemampuan tingkat artikulasi adalah kemampuan melakukan kegiatan yang kompleks dan tepat sehingga hasil kerjanya merupakan sesuatu yang

${ }^{23}$ Kunandar, Penilaian Autentik (Penilaian Hasil Belajar Peserta Didik Berdasarkan Kurikulum 2013) Suatu Pendekatan Praktik Disertai dengan Contoh (Jakarta: Rajawali Press, 2013), hlm. 255-256 utuh. Sebagai contoh, peserta didik dapat mengejar bola kemudian memukulnya dengan cermat sehingga arah bola sesuai dengan target yang diinginkan. Dalam hal ini, peserta didik suda dapat melakukan tiga kegiatan yang tepat, yaitu lari dengan arah dan kecepatan tepat serta memukul bola dengan arah yang tepat pula.

5) Naturalisasi

Kemampuan tingkat naturalisasi adalah kemampuan melakukan kegiatan reflek, yakni kegiatan yang melibatkan fisik saja sehingga efektivitas kerja tinggi. Sebagai contoh tanpa berpikir panjang peserta didik dapat mengejar bola kemudian memukulnya dengan cermat sehingga arah bola sesuai dengan target yang diinginkan.

\section{Kelebihan dan Kelemahan Penilaian Kom- petensi Keterampilan}

Kelebihan dari penilaian kompetensi keterampilan adalah: Dapat memberikan informasi tentang keterampilan peserta didik secara langsung yang bisa diamati oleh guru; Memotivasi peserta didik untuk menunjukkan kompetensinya secara maksimal; Sebagai pembuktian secara aplikatif terhadap apa yang telah dipelajarioleh peserta didik.

Sedangkan kelemahan dari penilaian kompetensi keterampilan adalah: Sulit dilakukan pada jumlah peserta didik yang terlalu banyak; Membutuhkan kecermatan dalam melakukan pengamatan terhadap unjuk kerja peserta didik dalam kompetensi keterampilan; Menuntut profesionalisme guru karena mengamati unjuk kerja peserta didik dalam kompetensi keterampilan yang bervariasi.

\section{Instrumen Penilaian Hasil Belajar}

Menurut Permendikbud, Strandar Penilaian Pendidikan adalah kriteria mengenai mekanisme, prosedur dan instrumen penilaian hasil belajar siswa. Penilaian hasil belajar siswa mencakup kompetensi sikap, keterampilan dan pengetahuan yang dilakukan secara seimbang, untuk mengetahui bahwa setiap siswa sudah sesuai dengan standar yang ditetapkan. Muatan di dalam penilaian antara lain, ruang lingkup materi, kompetensi mata pelajaran/kompetensi muatan/kompetensi program dan proses. ${ }^{24}$ Adapun teknik dan instrumen penilaian, sebagai berikut :

1. Instrumen penilaian kompetensi sikap yaitu:(1) Observasi, dilakukan secara berkesinambun-

${ }^{24}$ Sunarti dan Selly Rahmawati. 2014. Penilaian Dalam Kurikulum 2013. ... hal $115-117$ 
gan baik secara langsung maupun tidak langsung perilaku siswa; (2) Penilaian diri, meminta siswa mengemukakan kelebihan dan kekurangan dirinya dalam pencapaian kompetensi; (3) Penilaian antarsiswa, siswa saling menilai terkait dengan pencapaian kompetensi; (4) Jurnal, merupakan catatan guru baik di dalam maupun di luar kelas, mengenai kekuatan dan kelemahan siswa.

2. Instrumen penilaian kompetensi keterampilan, yaitu: (1) Penilaian kerja, siswa mendemonstrasikan suatu kompetensi tertentu dengan praktek, proyek dan portofolio; (2) Tes praktek, penilaian yang menuntut respons berupa perilaku yang sesuai dengan tuntutan kompetensi; (3) Projek, tugas belajar yang meliputi kegiatan perancangan, pelaksanaan dan pelaporan baik tertulis maupun lisan dalam waktu tertentu; (4) Portofolio, berupa kumpulan seluruh karya siswa yang bersifat reflektif-integratif, dapat berbentuk tindakan nyata yang mencerminkan kepedulian siswa terhadap lingkungannya.

3. Instrumen penilaian kompetensi pengetahuan, yaitu: (1) Tes tulis, berupa PG, isian, jawaban singkat, benar-salah, menjodohkan dan uraian; (2) Tes lisan, berupa daftar pertanyaan; (3) Penugasan, berupa pekerjaan rumah dan proyek yang dapat dikerjakan individual maupun kelompok sesuai dengan karakteristik tugas.

Berdasarkan penjabaran di atas, instrumen penilaian harus memenuhi persyaratan: mempresentasikan kompetensi yang ada dinilai, susunan penilaian memenuhi persyaratan teknis sesuai dengan bentuk instrumen yang digunakan, dan penggunaan Bahasa yang baik dan benar serta komunikatif sesuai dengan perkembangan siswa.

Prinsip yang paling penting dari penilaian autentik adalah dalam pembelajaran tidak hanya menilai apa saja yang sudah diketahui oleh siswa, tetapi juga menilai apa yang dapat dilakukan oleh siswa setelah pembelajaran selesai. Sehingga kualitas hasil belajar dan kerja siswa dalam menyelesaikan tugas dapat terukur.

Berdasarkan pernyataan di atas dapat dipahami bahwa betapa pentingnya bagi pengelola suatu lembaga pendidikan apapun bentuk dan tingkat satuan penddikannya untuk konsisten melaksanakan evaluasi pembebelajaran secara merata, berkelanjutan dan tuntas agar dengan hasil pendidikan yang diperoleh benar-benar dapat dipertannggungjawabkan baik secara mutu yang melingkupi meka- nisme input, pelaksanaan proses akademik dan output serta out come yang dapat menumbuhkan nilai kepercayaan publik yang baik.

Karena pada prinsipnya Evaluasi Pendidikan dapat dipahami sebagai proses membandingkan situasi yang ada dengan kriteria tertentu terhadap masalah-masalah yang berkaitan dengan pendidikan. Evaluasi pendidikan sebenarnya tidak hanya menilai tentang hasil belajar para siswa dalam jenjang pendidikan tertentu, melainkan juga berkenaan dengan penilaian terhadap berbagai aspek yang mempengaruhi proses belajar siswa tersebut, seperti evaluasi terhadap guru, kurikulum, metode, sarana prasarana, lingkungan dan sebagainya. Secara umum ruang lingkup dari evaluasi dalam bidang pendidikan di sekolah mencakup tiga komponen utama yaitu: Evaluasi program pengajaran, Evaluasi proses pelaksanaan pengajaran, dan Evaluasi hasil belajar.

Begitu juga secara operasional evaluasi pembelajaran merupakan salah satu bagian penting dalam sebuah kurikulum yang tidak dapat dipisahkan. Evaluasi pembelajaran berperan penting dalam menentukan sukses atau tidaknya proses pembelajaran yang dilakukan selama ini sekaligus dapat mempengaruhi proses pembelajaran selanjutnya. Evaluasi dalam pembelajaran merupakan suatu proses berkelanjutan tentang penilaian terhadap siswa yang diperoleh guru dari nilai ujian dan nilai keseharian siswa dalam proses pembelajaran. Kemudian nilai-nila tersebut diolah, dianalisis dan ditafsirkan untuk menilai keputusan-keputusan yang dibuat dalam merancang suatu sistem pembelajaran selanjutnya.

Dengan melakuan evalusai pembelajaran seorang guru dapat mengetahui sejauh mana pencapaian seorang siswa dalam mengikuti proses pembelajaran yang sudah diikutinya. Sehingga selanjutnya dapat memutuskan beberapa tindakan yang diperlukan (solusi) agar siswa tersebut dapat mengejat ketertinggalannya dalam pencapaian terhadap pemahaman materi tertentu seperti mengambil tindakan dengan menambah jam belajar diluar jam belajar sekolah.

\section{Kesimpulan}

Evaluasi Pendidikan dapat diartikan sebagai proses membandingkan situasi yang ada dengan kriteria tertentu terhadap masalah-masalah yang berkaitan dengan pendidikan. Evaluasi pendidikan sebenarnya tidak hanya menilai tentang hasil belajar para siswa dalam jenjang pendidikan tertentu, me- 
Ali Akbarjonol Ekspansi “TRUST" Dalam Evaluasi Pendidikan 189

lainkan juga berkenaan dengan penilaian terhadap berbagai aspek yang mempengaruhi proses belajar siswa tersebut, seperti evaluasi terhadap guru, kurikulum, metode, sarana prasarana, lingkungan dan sebagainya. Secara umum ruang lingkup dari evaluasi dalam bidang pendidikan di sekolah mencakup tiga komponen utama yaitu: Evaluasi program pengajaran, Evaluasi proses pelaksanaan pengajaran, dan Evaluasi hasil belajar.

Evaluasi pembelajaran merupakan salah satu bagian penting dalam sebuah kurikulum yang tidak dapat dipisahkan. Evaluasi pembelajaran berperan penting dalam menentukan sukses atau tidaknya proses pembelajaran yang dilakukan selama ini sekaligus dapat mempengaruhi proses pembelajaran selanjutnya. Evaluasi dalam pembelajaran merupakan suatu proses berkelanjutan tentang penilaian terhadap siswa yang diperoleh guru dari nilai ujian dan nilai keseharian siswa dalam proses pembelajaran. Kemudian nilai-nila tersebut diolah, dianalisis dan ditafsirkan untuk menilai keputusankeputusan yang dibuat dalam merancang suatu sistem pembelajaran selanjutnya.

Kepercayaan yang terbina di kalangan publik merupakan salah satu faktor yang turut mendorong kesuksesan pengelolaan suatu lembaga pendidikan. Kepercayaan merupakan motivasi yang mendorong masyarakat atau publik untuk terlibat aktif dalam membangun dan memajukan lembaga pendidikan itu sendiri. Tanpa adanya kepercayaan yang terbangun dan terbina dengan baik, masyarakat hanya sebagai penonton yang memiliki karakter apatis terhadap upaya pengembangan mutu baik mulai dari mutu input, proses dan output.

\section{Daftar Pustaka}

Doney. Toward A Trustful B To B Relationship.published in International Journal of Business and Management. October, 2009.

Fathurrohman dan Sutikno. 2010. Strategi Belajar Mengajar. Bandung: Refika Aditama.

Goetsch, David L dan Stanley B. Davis. Quality management: introduction to total quality management for production, procesing, and services. (USA Prentice Hall. 2000). h.258.http://aquariuslearning.co.id/membangun-kepercayaandalam-organisasi/.

Kim, S. \& Lee, H. (2006). The impact oforganizational context and information technology on employee knowledgesharing capability. Public Administration Review. 66, 3. Diakses dari www. blackwellsynergy.com pada tanggal 3 Mei 2015.

Kouzes, J. M., \& Posner, B.Z. The Leadership Chal- lenge, 4th eds., (John Wiley and Sons. 2007). h. 56.

Kunandar, 2013. Penilaian Autentik (Penilaian Hasil Belajar Peserta Didik Berdasarkan Kurikulum 2013) Suatu Pendekatan Praktik Disertai dengan Contoh Jakarta: Rajawali Press. hal 103-104.

Kunandar, 2013. Penilaian Autentik (Penilaian Hasil Belajar Peserta Didik Berdasarkan Kurikulum 2013) Suatu Pendekatan Praktik Disertai dengan Contoh.... hal 165-170

Kurniasih, Imas \& Sani, Berlin. (2014). Implementasi Kurikulum 2013 Konsep \& Penerapan. Surabaya: Kata Pena. hal $86-87$

Mayer et al. 1995. Academy of Management Review. downloaded from http://www.ooa.nl/ download/?id=16112122.

Morgan, Robert M dan Shalby D. Hunt. 1994. The commitment- trust theory. Published in Journal of marketing, July 1994. h. 23.

Nonaka, I. \& Takeuchi, H. The knowledge creating company. How Japanese companies create the dynamics of innovation. (New York: oxford university press. 1995).

Rasyid, dkk. 2007. Penilaian Hasil Belajar. Bandung: CV. Wacana Prima. hal 78

Robbins, Stephen P. And Timothy A.Judge. 2011. Organizational Behavior. (New York: Prentice Hall.2011). h. 395.

Sanjaya, Wina. 2010. Strategi Pembelajaran Berorientasi Standar Proses Pendidikan. Jakarta: Kencana.

Starnes, Becky J. et.al. A Primer on Organizational Trust. Downloaded from http://rube.asq.org/ hdl/2010/06/a-primer-on-organizational-trust. pdf.

Sunardi Nur \& Sri Wahyuningsih, Psikologi Pendidikan, Jakarta : PT Grasindo, 2002, hal : 28

Sunarti dan Selly Rahmawati. 2014. Penilaian Dalam Kurikulum 2013. Yogyakarta: Penerbit Andi. hal 98

Syamsu Yusuf \& Nani Sugandhi, Perkembangan Peserta Didik, Jakarta : Rajawali Press, cet -3 , 2012.

Undang-Undang Nomor 20 tahun 2003 tentang sistem pendidikan nasional, pasal 1 ayat 1

Wahyudin, Dinn. 2002. Pengantar Pendidikan. Jakarta:Universitas Terbuka

Wibowo. Manajemen Perubahan, (Jakarta: PT Raja Grafindo Persada, 2006). h. 376

Wina Sanjaya, Strategi Pembelajaran, Jakarta : Kencana, cet- 8,2011 , hal : 21 
Ali Akbarjonol Ekspansi “TRUST” Dalam Evaluasi Pendidikan 190 